Şırnak Üniversitesi

Ilahiyat Fakültesi Dergisi

Sayı 26 Haziran 2021

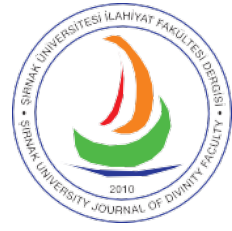

e-ISSN 2667-6575
Şırnak University

Journal of Divinity Faculty

Issue 26 June 2021

\title{
Yeni Bir Varlık Türü Olarak Biyoteknolojik Varlıklar ve Adalet Sorunu
}

Biotechnological Assets as a New Type of Entity and the Problem of Justice

\section{Nazan YEŞİLKAYA}

Dr., Şırnak Üniversitesi, İlahiyat Fakültesi, Felsefe Tarihi Ana Bilim Dalı PhD, Şırnak University, Faculty of Divinity, Department of History of Philosophy Şırnak, Turkey nkorkunc14@gmail.com https://orcid.org/0000-0002-9628-3492

Makale Bilgisi / Article Information

Makale Türü / Article Types: Araştırma Makalesi / Research Article

Geliş Tarihi / Received: 24 Mart / March 2021

Kabul Tarihi / Accepted: 18 Mayıs / May 2021

Yayın Tarihi / Published: 15 Haziran / June 2021

Sayı / Issue: 26 Sayfa / Pages: 233-256

Atıf / Cite as: Yeşilkaya, Nazan. "Yeni Bir Varlık Türü Olarak Biyoteknolojik Varlıklar ve Adalet Sorunu [Biotechnological Assets as a New Type of Entity and the Problem of Justice]". Şirnak Üniversitesi Illahiyat Fakültesi Dergisi - Şırnak University Journal of Divinity Faculty 26 (June 2021), 233256. https://doi.org/10.35415/sirnakifd.902464

Etik Beyanı / Ethics Declaration: Bu makalede bilimsel araştırma ve yayın etiği ilkelerine riayet edilmiştir. Makale etik izin gerektirmeyen bir çalışma olup en az iki hakem tarafından incelenmiş ve intihal içermediği teyit edilmiştir./ In this article, the principles of scientific research and publication ethics are respected. The article is a study that does not require ethical permission. It has been reviewed by at least two referees and was confirmed that it did not contain plagiarism.

Copyright $($ Published by Şırnak Üniversitesi, İlahiyat Fakültesi / Şırnak, Türkiye (Şırnak University, Faculty of Divinity, Şırnak, 73000 Turkey). 


\section{Özet}

Günümüz dünyasında bedenleri teknoloji ile bütünleşmiş, insanın muadili olarak lanse edilen siborg veya yarı robot-yarı insan gibi biyoteknolojik varlıkların 21. yüzyılın parçası olacağ1 düşünülmekte olup yapay zekâ ve sibernetik uygulamaların yakın zamanda hem doğrudan hem de dolaylı olarak hukuk alanına sirayet edeceğini söylemek mümkündür. Özellikle de bu varlıkların "ötekileştirilme" sorunuyla yüz yüze gelmesi ve "öteki" kılınmalarına dair itirazları genellikle hak, özgürlük ve eşitlik talepleri şeklinde gündeme gelebilmektedir. Söz konusu durumun neticesinde genetik yapısı biyoteknolojik uygulamalarla farklılaşanlara yönelik bir ayrım gözetmek, ayrıcalık göstermek veya onları dışlamak şeklinde tarif edebileceğimiz bir "ötekileştirme" ve kimlik sorunu söz konusu olabilecektir. Ortaya çıkacak olan yeni posthümanist durumla beraber avantajlı ve dezavantajlı konumda olacak öznelerin eşitsizlik ve adaletsizlik söylemleri yakın zamanda yaygınlık kazanacak ve bu husus hassas bir sorun olarak belirecektir. Bu çalışma; biyolojik seleksiyona beşerî müdahalenin dahil olmasıyla gerçekleşen, bedenleri teknoloji ile bütünleşmiş ve insanın alternatifi olan varlık türü olarak lanse edilen siborg veya yarı robotyarı insan gibi biyoteknolojik varlıkların hem doğrudan hem de dolaylı olarak hukuk alanına sirayet etmesine işaret etmektedir. Çağdaş felsefe kuramcılarının odağında yer alan, Batı dünyasının teknolojiye sunduğu sınırsız öncelik ile insani gelişim adına yürütülen yeni teknoloji uygulamalarının evrenselleşerek insan doğasını değiştirmesinin etik ve politik anlamda yeni adaletsizliklere yol açabileceği ve bu durumun her şeyin toptan bir yıkımından başka bir şey vaat etmeyeceği düşüncesi söz konusu çalışmanın ana problemidir. Özne ile adalet ilişkisinin ortaya çıkışında modernliğin insanı bilgi nesnesine dönüştürmesi ve insanlığ1 üzerinde çalışılan bir nesneye indirgemesi adalet sorunsalının felsefi dönüşümüyle de yakından bağlantılı olduğu için çalışmamız, günümüz teknolojilerinin insan doğasının geleceğine ne şekilde yansıdığını dikkate alarak post-human'ın adaleti ve hukuku ne şekilde dönüştüreceğini etik ve politik bir perspektiften tartışmak suretiyle konuyla ilgili beliren adalet sorunlarını gündeme taşımayı amaçlamaktadır. Çağımıza dair en kaygı verici sorunlardan biri kuşkusuz ontolojik sınırların bulanıklaşmasıyla insan tanımlarının/tasvirlerinin tehlike altında olması ve bu hususun adalete olduğu kadar hukuka yansımalarının da ciddi boyutlara varabilmesidir. İnsanın biyoteknolojik müdahalelerle almış olduğu yeni hâl sadece etik alanını değil politik ve hukuki zemini de kapsayacak biçimde tartışılması gereken bir durumdur. Çalışmamız, sözü edilen sorunlara hukuk ve adalet düzleminde katkı sunma imkânını araştırarak post-antropolojik felsefeler bünyesinde beliren eleştirileri değerlendirmeyi ve çağımızın önemli sorunu olan adalet anlayışına felsefi bir katkı sunmayı hedeflemektedir. Ayrıca, posthümanist çağda yapay zekâ, robotik ve insan genomu gibi düzenlemelerle insanlığın yeniden tanımlanması ve bu durumun hukuk ve adalete etkilerini düşünmeye zaman harcanması gerektiğini savunmakta ve yeniden icat etmek durumunda kaldığımız yaşam pratiklerinden biri olan hukuk biliminin yapay zekâ ve yapay yaşamla ilgili tutumunu geliştirmesi gerektiği kanaatini gerekçeleriyle ve transhümanist çalışmalara atıfla ortaya koyma çabasındadır. Sonuç olarak bu çalışma, gelecek nesillerin insanca yaşaması ve adaletin anlam bütünlüğünün zedelenmemesi için bilim ve teknoloji etkinliğinin hukuk dünyasındaki gereksinimlere ve etik değerlere uygunluk ve kabul edilebilirlik açısından gözden geçirilmesi ve tesis edilmesi gerektiğini savunmaktadir.

Anahtar Kelimeler: Felsefe Tarihi, Post-Antropolojik Felsefeler, Post-Human Hukuk Dönemi, Biyoteknolojik Varlıklar, Siborg, Bilişsel Melezleşme, Genişletilmiş Zihin, Adalet. 


\section{Summary}

In today's world, it is thought that biotechnological entities such as cyborgs, whose bodies are integrated with technology and introduced as the equivalent of humans, will be a part of the 21st century. It is possible to say that artificial intelligence and cybernetic applications will spread to the field of law both directly and indirectly in the near future. These entities face the problem of "otherization" and their objections to being made "other" can be counted as demands for rights, freedom, and equality. As a result of this situation, there may be a problem of "otherization" and identity, which we can describe as discrimination, showing privilege or excluding those whose genetic structure is differentiated by biotechnological applications. Along with this new post-humanist situation that will emerge, the discussions of inequality and injustice of subjects who will be in an advantageous and disadvantaged position will soon become widespread, and this issue will appear as a sensitive problem. This study points out the effect of biotechnological assets such as cyborgs on the field of law both directly and indirectly. The idea that the Western world, which is at the center of contemporary philosophical theorists, offers unlimited priority to technology and that the universalization of new technology applications carried out for human development and changing human nature may lead to new injustices in ethical and political terms, and that this situation will promise nothing but wholesale destruction of everything is the main problem of the study. In the emergence of the relationship between the subject and justice, the transformation of humans into the objects of knowledge and the reduction of humanity to an object of study by modernity is closely related to the philosophical transformation of the problem of justice. For this reason, our study aims to bring the emerging justice problems to the agenda by discussing from an ethical and political perspective how the post-human will transform justice and law, taking into account how today's technologies reflect on the future of human nature. Undoubtedly, one of the most worrying problems of our time is that human definitions/descriptions are in danger due to the blurring of ontological boundaries, and the reflection of this issue on the law as well as on the justice can reach serious dimensions. In this study, the connection between the question of justice and the subject will be dealt with on an ethical and political basis. Our study aims to evaluate the criticisms emerging within the post-anthropological philosophies by investigating the possibility of contributing to the solutions of the law and justice problems, and to make a philosophical contribution to the understanding of justice, which is an important problem of our age. In addition, the study argues that in the post-humanist age, it is necessary to redefine humanity with elements such as artificial intelligence, robotics, and the human genome, and to spend time thinking about the effects of this situation on law and justice. It also tries to put forward the belief that the science of law, which is one of the life practices that we have to reinvent, should improve its attitude towards artificial intelligence and artificial life, with justifications and with reference to transhumanist studies. As a result, this study argues that the activities of science and technology should be reviewed and established in terms of compliance and acceptability with the requirements and ethical values in the world of law to ensure that future generations live humanely, and that integrity of justice is not damaged.

Keywords: History of Philosophy, Post-Anthropological Philosophies, Post-Human Jurisprudence, Biotechnological Entities, Cyborg, Cognitive Hybridization, Expanded Mind, Justice. 


\section{Giriş: Teknolojiyle Bütünleşen Bedenler ${ }^{1}$}

İnsan zihninin sınırlarını ve kapasitesini çoktan aşmış olan sentetik varoluşun artık bir bedene gereksinim duymadığı ve modern küresel rasyonalite düşüncesinin sunduğu meta anlatılarının, yerini mini irrasyonalitelere ikame ettiği bir dönemde olduğumuzu hatırda tutacak olursak önemli bir tarihsel başkalaşımın ortasında yaşamakta olduğumuz şüpheye yer bırakmayacak şekilde aşikâr görünüyor. Yapay insanın tasvir edildiği ve organik insan tasavvurunun sonuna gelindiği 21. yüzyılda biyoteknoloji ve nöro-farmakoloji gibi teknoloji bazlı müdahalelerle gerçekleşen insan doğasının uğrayabileceği değişiklikler, insan yetiştirme metaforunda ifadesini bulurken bu durum çağdaş kuramcıların sıklıkla vurguladığ 1 ciddi bir sorun olarak belirmektedir.

Öyle ki günümüz dünyasında bedenleri teknoloji ile bütünleşmiş, insanın muadili olarak lanse edilen siborg veya yarı robot-yarı insan gibi biyoteknolojik varlıkların 21 . yüzyılın parçası olacağı düşünülmekte olup yapay zekâ ve sibernetik uygulamaların yakın zamanda hem doğrudan hem de dolaylı olarak hukuk alanına sirayet edeceğini söylemek mümkün. ${ }^{2}$ Özellikle de bu varlıkların “ötekileştirilme” sorunuyla yüz yüze gelmesi ve “öteki” kılınmalarına dair itirazları genellikle hak, özgürlük ve eşitlik talepleri şeklinde gündeme gelebilmektedir. Söz konusu durumun neticesinde genetik yapısı biyoteknolojik uygulamalarla farklılaşanlara yönelik bir ayrım gözetmek, ayrıcalık göstermek veya onları dışlamak şeklinde tarif edebileceğimiz bir "ötekileştirme” ve kimlik sorunu söz konusu olabilecektir. Ortaya çıkacak olan yeni posthümanist durumla beraber avantajlı ve dezavantajlı konumda olacak öznelerin eşitsizlik ve adaletsizlik söylemleri yakın zamanda yaygınlık kazanacak ve bu husus hassas bir sorun olarak belirecektir.

Entelektüel anlamda pek çok sahada çağımıza yön veren yeni ve çok önemli gelişmelerin (nanoteknoloji, yapay zekâ, yapay yaşam, hücresel otomasyon³, genişleyen evren, bulanık mantık, süper cisimler vb. ilerlemeler) hukuk alanı ve adaletle olan etkileşimi oldukça merak uyandırıcı görülmektedir. Çünkü neredeyse gezegenimizdeki tüm canlıların

1 Bu çalışma "Post-Antropolojik Felsefelerde Adaletin İmkânı" başlıklı doktora tezi esas alınarak hazırlanmıştır./ This article is extracted from doctorate dissertation entitled "The Possibility of Justice in PostAnthropological Philosophies" (PhD Dissertation, Ankara University, Ankara/Turkey, 2020).

2 Kafasına yerleştirilmiş bir antene sahip ilk kişi olması ve hükümetçe yasal anlamda bir cyborg olarak tanınan Neil Harbisson, 2004 yılından beri uluslararası medya tarafından da dünyanın ilk siborgu olarak tanınmaktadır. Ayrıca Moon Ribas, ayaklarına takılan çevrimiçi sismik sensörler yoluyla titreşimleri algılayarak depremleri hisseden ve 2007 yılından bu yana uluslararası medya tarafından dünyanın ilk siborg kadını olarak lanse edilmektedir. Bk. Cyborg Foundation (Erişim 28 Nisan 2021).

3 Hücresel otomasyon doğadaki süreçleri simüle etmek için kullanılır. 
yaşamını bu gelişmeler doğrudan etkileyebilmektedir. Bu bakımdan insanın gerek varoluşunun boyutu ve temsil ettiği insani değerin eskiliğine gerekse adaletle olan bağına ilişkin derinlemesine bir felsefi ve etik sorgulamaya gerek duyulduğu kanaatindeyiz.

Bilimsel ve teknolojik uygulamaların kapitalist sermayenin hizmetinde olduğuna dair artık herkesçe ileri sürülen iddialar, biyolojik seleksiyona beşerî müdahalenin dahil olması ile birleştirildiğinde insanın bedeniyle birlikte aklının etkileyici mimarisinin de değiştirilip dönüştürülmesi gündeme gelecek ve böylelikle insanı insan yapan değerlerde tahribattan söz edilebilecektir. Bir başka deyişle, kâr odaklı bilim ve ticaret ortaklığının egemen olması ve bunların politikayla karşılıklı etkileşim halinde olması büyük bir güce dönüşebilmekte ve bahsi geçen gücün insanlık üzerindeki olumsuz etkileri sıklıkla eleştirilmektedir. Foster'in de belirttiği üzere insanlık ya bilime nüfuz eden egemen ideolojiden ayrılarak ekolojik sorunlar adına gerek doğanın gerekse insanın uyum içinde olduğu ve kapitalist menfaatlere hizmet etmeyen eşitlikçi bir toplumsal yaşam arayışı içinde olacak yahut tüm canlılarla beraber yıkıcı bir ekolojik ve toplumsal krizle yüzleşecektir. ${ }^{4}$

Çağımıza dair en kaygı verici sorunlardan biri kuşkusuz ontolojik sınırların bulanıklaşmasıyla insan tanımlarının/tasvirlerinin tehlike altında olması ve bu hususun adalete olduğu kadar hukuka yansımalarının da ciddi boyutlara varabilmesidir. İnsanın biyoteknolojik müdahalelerle almış olduğu yeni hâl sadece etik alanını değil politik ve hukuki zemini de kapsayacak biçimde tartışılması gereken bir durumdur. Özne ile adalet ilişkisinin ortaya çıkışında modernliğin insanı bilgi nesnesine dönüştürmesi ve insanlığı üzerinde çalışılan bir nesneye indirgemesi adalet sorunsalının felsefi dönüşümüyle de yakından bağlantılı olduğu için bu çalışmada adalet sorunsalının özneyle olan bağlantısı etik ve politik bir zeminde ele alınacaktır. Çalışmamız sözü edilen sorunlara hukuk ve adalet düzleminde katkı sunma imkânını araştırarak post-antropolojik felsefeler bünyesinde beliren eleştirileri değerlendirmeyi ve çağımızın önemli sorunu olan adalet anlayışına felsefi bir katkı sunmayı hedeflemektedir.

\section{Post-human Hukuk Dönemi}

Nietzsche ve Nietzsche sonrası postyapısalcı ve postmodern düşünce hattını kapsayan post-antropolojik felsefeler, "insan özne"nin eleştirisini muhteva eden aynı zamanda yeni insan telakkilerini ve insan olmayan özneleri de merkeze alarak ekolojiden

4 John Bellamy Foster, Emperyalizmin Yeniden Keşfi, çev. Çiğdem Çidamlı (İstanbul: Devin Yayıncılık, 2005), 284285. 
kozmolojiye, teknolojiden biyolojiye, etikten hukuka, sosyolojiden politikaya kadar geniş bir söylemi barındıran felsefi tutumları içermektedir. Bu anlamda post-antropolojik felsefeler verili insanı konu edinirken imal edilmiş insanı da kapsayan, farklı disiplinleri içine alan, bütüncül ve kapsamlı bir çerçeveye sahip olmanın ötesinde modernizmin rasyonalizasyon anlatısına meydan okuyan felsefi tutumların (antihümanizm ${ }^{5}$, posthümanizm ${ }^{6}$, metahümanizm7, transhümanizm vd.) karmaşık bir tertibi olarak da tanımlanabilir.

Tıpkı antropoloji disiplini gibi geleneksel araştırma nesnesi olarak insana ve insanlığa odaklanan post-antropolojinin esas ayırt edici özelliği insan dişı aktörlerin araştırmaya eklemlenmesine dayanır. $\mathrm{Bu}$ bakımdan post-antropolojik felsefelerin panoramasını tanımlayacak olursak bir dizi ilginç fenomeni (biyo-teknoloji, nano-teknoloji, nörofarmakoloji, yapay zekâ teknolojileri vd.) içerdiğini ve bu içeriğe bağlı olarak yeni insan tasavvurlarının (teknolojideki devrimlerin gerek tıbbi ve askeri gerekse sanal ve biyo-teknik olsun ortaya koyduğu yeni varlığın $)^{8}$ post-antropolojik felsefelerde oldukça önemli bir kavram olan "post-human"9 adını aldığını ifade edebiliriz.

Posthuman veya post-human; bilim kurgu, fütüroloji, çağdaş sanat ve felsefe alanlarında ortaya çıkan ve kelimenin tam anlamıyla insan olmanın ötesini karşılayan bir kavramdır. Aynı zamanda genetik veya biyonik müdahale yoluyla insanlardan evirilebilecek varsayımsal/spekülatif bir türün üyesi olarak nitelenebilir. Bu kavram etik ve adalet, dil ve türler arası iletişim, sosyal sistemler ve disiplinler arası entelektüel konuları ele almaktadır.

5 Antihümanizm, felsefi antropoloji projesine karşı çıkan bazı düşünürlerce kullanılan bir terimdir. Nietzsche'nin 19. yüzyılda Tanrı'nın ölümünü ilan ettiği gibi anti-hümanizm de 20. yüzyıllardaki insan'ın ölümünü ilan etmektedir. Sosyal teori ve felsefede anti-hümanizm (ya da antihümanizm), geleneksel hümanizm ile insanlık ve insan durumu hakkındaki geleneksel fikirleri eleştiren bir teoridir. Antihümanizmin odağında "insan doğası", "insan" veya "insanlık" kavramlarının tarihsel olarak göreceli veya metafiziksel olarak reddedilmesi gerektiği görüşü vardır. Bk. J. Childers ve G. Hentzi (ed.), The Columbia Dictionary of Modern Literary and Cultural Criticism (New York: Columbia University Press, 1995) 100, 140-141.

6 Posthümanizm, insanlığın teknolojik gelişmeler veya evrimsel süreçle dönüştürülebileceği, aşılabileceği veya ortadan kaldırılabileceği fikri; bu inancı yansitan sanatsal, bilimsel veya felsefi uygulamadır. Bk. Oxford Dictionary, "Posthumanism" (Erişim 25 Nisan 2021).

7 Metahümanizm, hümanizmin özgür iradesi, özerkliği ve anthropoi'nin rasyonalitesinden dolayı üstünlüğü gibi bazı temel öncüllerinin bir eleştirisidir. Bk. Jaime del Val and Stefan Lorenz Sorgner, A Metahumanist Manifesto (Erişim 25 Nisan 2021).

8 Tüm bu uygulamalar aynı zamanda insan organizmasını radikal bir şekilde dönüştürmek için teknolojinin kullanılmasını savunan ve nihai hedefi "post-human" olma durumunu destekleyen transhümanizm hareketini yakından ilgilendirmektedir.

9 Bir önceki aşama varlı̆̆ı "transhuman"dır. Nasıl ki transhümanizm posthümanizme geçiş aşamasında ara dönemi temsil ediyorsa "transhuman" da "posthuman"a geçiş aşamasında ara varlığ temsil etmekte olup bu ara varlık biyo-biyonik bir varlıktır. Bk. Ahmet Dağ, Transhümanizm: İnsan ve Dünyanın Dönüşümü (Ankara: Elis Yayınları, 2018), 7. Ayrıca transhümanistler, kendimizi "post-human" olma noktasına kadar geliştireceğimize inanmaktadırlar. Bk. Shayma Abukar, Transhumanism: Biotechnology and its Role in the Singularity (Erişim 25 Nisan 2021). 
Post-human etrafında yeni alanların şekillenmesi felsefede olduğu gibi birçok disiplin için de yeni çalışma alanları olarak tebarüz etmekte olup post-antropolojik felsefelerin odağına insan olmayan aktörler ve yapay insan söylemleri de dahil edilerek insan tanımlarına dair skalayı genişletmektedir. Bu durum insana dair sınırların ortadan kalkması ve "yeni bir hukuk" yaklaşımının toplum yaşamına izdüşümü olarak yorumlanabilir.

Siyasal ve teknolojik açmazları inceleyerek hukuka ve adalete yönelik tartışmaları bilhassa toplumsal anlamda adalete ilişkin genel kaygı derecesini dikkate alarak posthuman'1, antroposen bir hat üzerinde değerlendirecek olursak söz konusu bu çağı Stiegler, dünya üzerindeki insan varlığının tüm sistemleri tahrip ettiği entropik bir karakter olarak niteler. ${ }^{10} \mathrm{Bu}$ noktada açı olan şu ki "hem kendisi hem de gezegenin sonunu kendi eliyle getiren modern öznenin artık kontrolü dışında dönen ve tüm metafizikleri, ideolojileri (faşizm, komünizm, liberalizm vb.) Tanrı'yı yıkıp geçen bir dünyada etik bir zemin nasıl mümkün olacaktır?" sorusu ve benzeri sorular post-human'ın yüzleşmek zorunda olduğu ciddi problemlerdir. Söz gelimi, insanların genetik yapılarının üçüncü şahıslar vasıtası ile önceden belirlenmesine müsaade etmek, insanın kimliğine yönelik bir saldırı olarak değerlendirilebilmekte ${ }^{11}$ olup söz konusu husus hukukun alanını fazlasılla meşgul edecek problemler arasina girmektedir.

Bu bakımdan insan ile hayvan ya da insan ile makine gibi türlerin sentezinin neden olduğu etik dışı uygulamaların adalet ve hukuk alanına izdüşümleri post-antropolojik felsefelerin sıklıkla gündemindedir. Söz gelimi bilgi teknolojileri ve biyo-teknoloji iş birliğinin türümüzü karşı karşıya bırakacağı zorluklardan biri de milyonlarca insanın iş dışına itilmesidir. Hükümetlerin dijital hakimiyeti, beraberinde özgürlüklerin kısıtlanmasını ve eşitsizliklerin artarak çoğalmasına neden olacaktır. Sözü edilen durumun neden olacağ hukuki sorunların yanı sıra işsizliği de beraberinde getirecek olması insanların kendilerini önemsiz ve gereksiz bir konumda bulmalarıla sonuçlanacak olup büyük bir sosyoekonomik açmaza ve ruhsal sorunlara da sebebiyet verecektir.

Post-antropolojik felsefelerin insan durumunu yeniden tanımlamaya yönelik çağdaş girişimin bir sonucu olarak gelişen farklı bakış açılarının ve hareketlerin devam eden bir süreci olduğunu varsayacak olursak yeni insan tasavvurlarının singularity, posthümanizm ve transhümanizm hareketleriyle olan yakın bağını ortaya koymakta fayda vardır. İnsan

10 Bernard Stiegler, “Antroposenden Çıkmak”, Cogito: Yerküre Krizi, Dönüşen İnsan, Sayı: 93 (İstanbul, Yapı Kredi Yayınları, 2019), 190.

11 İ. Seyalığlu vd. “Klonlamaya Genetik, Etik ve Hukuksal Açıdan Yaklaşım”, Adli Tıp Dergisi 21/2 (2007), 31-45. 
varlığının ekonomik ve siyasi ilişkiler ağı ve küresel nedensel bağlantıların kördüğümü içinde incelendiği post-antropolojik felsefelerin adalet ve hukuk hattında deneyimlenen değişimi ve dönüşümü daha net ortaya koyabilmek adına bu düşüncelerin genel muhteviyatına yer verilmesi konunun anlaşılmasına katkı sağlayacaktır.

Post-antropolojik felsefelerin bünyesinde yer alan transhümanizm fikriyatının biyoteknolojik varlıklarla olan ilişkisi dikkate alınacak olursa transhümanizmin insan ırkının, özellikle bilim ve teknoloji yoluyla, mevcut fiziksel ve zihinsel sinırlamalarının ötesine geçebileceği inancı yahut teorisi olarak tanımlandığı ifade edilebilir. ${ }^{12}$ Felsefi bir yaklaşım olarak transhümanizm anlayışı, bu yönüyle insan olmanın ötesine giden yeni bir anlayışa kapı aralamaktadır. ${ }^{13}$ Politikacılar ve akademisyenlerin yanı sıra teknoloji şirketleri gibi bir çok platformda transhümanizm hareketinin popülerliği artmakta olup bu durum insanlığın yakın gelecekte hızla "transhümanite”ye dönüşeceğinin güçlü sinyalleri olarak okunabilir.

Transhümanizm görüşünü aşırıya çekerek ele alan eleştirmenler, teknolojilerin varoluşsal riskleri tetikleme olasılığına işaret ederek daha güçlü teknolojilerin şefkatsizlik, katı yüreklilik ve egoizm gibi mevcut karakter kusurlarının etkisini de büyütebileceği ihtimali üzerinde dururlar. Buna göre insanlar, gelişmiş teknolojinin bir sonucu olarak daha akıllı ve daha güçlü hale gelebilir ancak aynı zamanda daha anlayışlı veya daha iyi kalpli olacaklarının bir garantisi yoktur. ${ }^{14}$ Ayrıca tehlikeli yeni hastalıkların patlak vermesi hususu çok daha ürkütücü ihtimalleri örneğin, genetik manipülasyon ile ilgili sorunları gündeme taşımaktadır. Kötü olasılıklar arasında yer alan bir diğer konu mahremiyet kaybıdır. Devlet veya şirketler tarafından daha fazla gözetim ve büyük veri analizinin olması gibi durumlarda daha fazla manipülasyona maruz kalacak olmamız olasıdır. Bu ihtimallerden hareketle belirtilmelidir ki insanı mükemmelleştirmeyi hedefleyen biyoteknoloji veya genetik mühendislik uygulamaları ne derece ileri seviyede olursa olsun insanın özünde yer alan temel duygulara sahip olma konusunda eksik kalacağa benziyor.

12 Bk. "Transhumanism”, Oxford Dictionary, (Erişim 25 Nisan 2021).

13 Max More'un "Transhumanism: Towards a Futurist Philosophy” çalışmasında bugünkü anlamına kavuşan transhümanizm kavramı bahsi geçen eserde "zeki yaşam formu evriminin, şu anki insan formunun ve insan sınırlamalarının ötesine bilim ve teknoloji yoluyla geçmesini ve hılanması arayışında bir yaşam felsefesi" olarak tanımlanmaktadır. Bk. Max More, “Transhumanism: Towards a Futurist Philosophy," Extropy (Erişim 25 Nisan 2021).

14 Bk. Future Fandom, “Transhumanism Criticisms” (Erişim 28 Nisan 2021). 
Açıkça belirtmek gerekirse bu dönemde post-human'ın doğa içindeki konumunu nasıl tanımladığı değişiklik arz etmektedir. Post-human söylemi, insan durumunu yeniden tanımlamaya yönelik çağdaş girişimin bir sonucu olarak gelişen farklı bakış açıları ve hareketlerin devam eden bir sürecidir. Bu bakımdan posthümanizm, yeni ortaya çıkan teknolojiler bağlamında insan olmanın ne anlama geldiğine dair felsefi görüşleri yeniden düzenleme girişimi olduğu kadar felsefe tarihinin de belli bir okumasıdır.

Braidotti söz konusu dönem için yeni meta anlatıların baskın olmaya başladığını ve bahsi geçen anlatıların bize oldukça tanıdık geldiğinin altını çizer. Sözü edilen anlatılar bir yönüyle insanlığın ilerlemesinin tarihsel bakımdan dominant hali olarak beliren pazar ekonomilerinin kaçınılmazlığı olurken diğer yönüyle "bencil gen"15 (the selfish gene) ve yeni evrimsel biyoloji ve psikoloji kisvesiyle iş gören biyolojik özcülük meselesidir. ${ }^{16}$ Pazar ekonomilerinin baskın olması ve biyolojik özcülük argümanlarının yanı sıra biyoloji biliminin, statükonun korunması adına kullanılması endişe verici bir duruma sebebiyet vermekte olup söz konusu husus hukuk alanında önemli bir yeri iştigal etmektedir.

Tüm bu değerlendirmelerden de anlaşılacağı üzere biyolojik insanın sahip olduğu hak ve özgürlüklerin sentetik/hibrit/melez/yapay/kurgusal varlıklar için de geçerli olması gerektiği yönündeki post-antropolojik felsefelerin tartıştığı argümanlar aynı zamanda politika ve hukuk etkileşimiyle yakından ilgilidir. Nitekim varlık, siborg veya robotik varlıkların gündeme gelmesiyle adeta boyut değiştirmekte ve insan dişındaki varlıkların hak talepleri sorunu ortaya çıkmaktadır.

“Makinelerin kendi kararlarını kendilerinin vermesine olanak verilmesi durumunda insan türünün kaderi artık makinelerin eline mi geçecektir?" sorusu son derece önemli bir meseledir. Bu durum biyo-politika çağının antropolojisini fazlasıyla meşgul eden bir sorun haline dönüşmektedir. Bu noktada Çeçen'in haklı ifadesine yer verecek olursak, mantıksal olduğu kadar duygusal yönleri olan bir kavram olarak adalet, her insanda doğuştan var olan ve giderek gelişen bir duygu olarak salt insana özgü bir niteliktir. ${ }^{17}$ Dolayısıyla adil karar vermek adına hukukun veya adaletin sağlayıcısı olarak bu niteliklerden yoksun robotların hakkaniyetli bir yargılama yapıp yapmayacağı da merak konusudur.

15 Richard Dawkins tarafından evrim üzerine yayımlanan kitapta Dawkins, bencil gen kavramıyla evrimin etkilerinin genler üzerinde en mükemmel biçimde görülebileceğini savunur. Bk. Richard Dawkins, The Selfish Gene (Oxford: Oxford University Press, 1976).

16 Rosi Braidotti, “Feminist Post-Postmodernizmin Eleştirel Bir Kartografyası", Cogito: Feminizm Sayı: 58, (İstanbul: Yapı Kredi Yayınları, 2009), 225.

17 Anıl Çeçen, Adalet Kavramı (İstanbul: Gündoğan Yayınları, 1993), 22. 
Yapay zekâ veya robotların hukuk alında aktif rol üstlenmelerinin hukuk sahasında oluşturacağı olumlu ve olumsuz etkilerin yanı sıra bir diğer kritik mesele siborg veya robotların vatandaşlık hakları sorunudur. Nitekim Avrupa Birliğince 2017 yılında robotlara kimlik verilmesi karara bağlandı. Böylelikle gelecekte robot olduğunu gizleyebilecek androidlerin ve siborgların aramızda olacağına kesin gözüyle bakabiliriz. ${ }^{18}$ Siborgların cinselliği, çoğaltımı ve bireyselleşmesi belirginleştikçe türlerin ve cinsel yönelimlerin ötesine geçecek toplumların mümkün olabileceğini belirten Donna Haraway ise Siborg Manifestosu'nda insan ve robot (makine) arasındaki ayrımların muğlaklığına dikkat çeker. ${ }^{19}$ "İnsanın ölümü" sonrasında ve post-human bir figür olarak tanımlayacağımız siborg kavramını Haraway, “bir makine-organizma melezi, kurguya yakın olduğu kadar toplumsal gerçeğe de ait bir yaratı" şeklinde ifade ederken aslında siborg yoluyla akıl-beden, insanhayvan, kadın-erkek şeklinde hapsolduğumuz ikiciliklerden çıkmamıza olanak sağlar. ${ }^{20}$

Kurzweil'e göre makineler kimliğimizin bir parçası ve makinelere karşı "biz” diye bir şey yok çünkü bu ikisinin bir karışımı olacağız ve elbette biyolojik olmayan bölüm baskın gelecektir. ${ }^{21}$ Dolayısıyla geleceğin toplumunda avantajlı ve dezavantajlı olarak kategorize edilebilecek öznelerin hak talepleri ve eşitlik istemleri hukuka yansıyan konular arasına girecektir. Ayrıca biyolojik insanın biyoteknoloji/moleküler-biyoloji/nöro-farmakoloji/nanoteknoloji/genetik mühendisliği gibi yeni güçler ile bütünleşmesi sonucunda insan şeklinin değişikliğe uğraması söz konusu olurken esas mesele sadece insan şeklinin uğrayacağı olası durumla sınırlı değildir, insan özünün de ciddi bir değişim ve dönüşüme tabi olacak olmasidir.

Ortaya çıkan yeni insan söylemi belki de ne Nietzsche'nin üst insanı ne de Marx ya da Stalin' in düşlediği kitlelerin köleleştirilmesi uğruna putlaştırılan "yeni insan” ya da "tam insan"1 değildir. Bu, daha ziyade bilimsel ve teknolojik ilerlemeler yoluyla kendi elimizle inşa ettiğimiz ve gezegene egemen olma arzusu uğruna türümüzün kısa vadede yok olup tükeneceğine dair bir söylemle eş tutulan bir posthumanity durumudur. Bu bakımdan geleceğin toplumunda gerek ayrı bir toplumsal sınıf oluşturmaya aday siborgların gerekse

18 Can Batukan, Robo-tizm: Robot, Android, Sayborg ve Yapay Zekâda Ruh Üzerine (İstanbul: Altıkırkbeş Yayınları, 2017), 25.

19 Donna Haraway, A Cyborg Manifesto Science, Technology, and Socialist-Feminism in the Late Twentieth Century, (Minnesota: University of Minnesota Press, 2016), 6-60.

20 Donna Haraway, Başka Yer, çev. Güçsal Pusar (İstanbul: Metis Yayınları, 2010), 46.

21 Andy Walker vd., Süper İnsan Teknoloji İnsanlığı Yeniden Tanımlıyor, çev. Su Evren (İstanbul: Siyah Kitap, 2019), 274. 
androidlerin değişik modelleri olan yarı robot yarı insan şeklinde insanla bütünleşmiş varlıklar, genetik olarak yükseltilmiş insanlar ve normal insanlardan oluşan sınıfların varlığı göz önünde bulundurulursa transhümanizm ve posthümanizmin edimselleşeceği bir toplumu ve bu toplumun hukuk sahasında ciddi değişim ve dönüşümleri kapsayacağını tahayyül edebiliriz.

Böylesi bir toplumda "Biyolojik zihinlerimizle makine zihinlere adaleti ve etiği öğretmemiz mümkün mü?" sorusu muğlaklığını korumaktadır. Biyoteknoloji uygulamalarındaki hız ve artış, ekonomik ve sosyal eşitsizliklerdeki²2 artışla birleşerek postantropolojik felsefelerin odağ ${ }_{1}$ olan yeni insan metaforunun yok edici etkilerinin beraberinde getirdiği krizi derinleştirmekte ve adaletle ilgili problemleri gün yüzüne çıarmaktadır. Nitekim son yıllarda yasa koyucunun terapötik klonlama, ${ }^{23}$ reprodüktif klonlama, ${ }^{24}$ taşıyıcı annelik, ötenazi uygulamalarını yürürlüğe koyması yahut yasaklaması gibi girişimler, hukuk sahasını fazlasıyla meşgul etmektedir. Çünkü biyo-teknolojiler²5 “döllenme, embriyo gelişimi, doğum, cinsellik, yaşlanma ve ölüm üzerine etki ederek özne konumundaki kişiyi oluşturan ve bireyselleştirme sürecine dahil olan hayati normlarda saklı koşulları değiştirir." 26 Tüm bu koşullar hukuka sirayet eden kritik mevzular olarak yüzleşmemiz gereken konular arasındadir.

Açıkça belirtmek gerekirse döllenmenin bu derece alt üst oluşu hukuka ve adalete dair ciddi açmazlara sebebiyet vermektedir. Söz gelimi ana rahminde teşhis yöntemi tedaviye yönelik bir amaç taşıdığı için iyi olarak nitelendirilebilirken başka bir durumda kötünün somutlaşması olarak algılanacaktır. Tıpkı Nazi öjenizminde olduğu gibi ırkçı seleksiyona açılan bir kapı olarak görülecektir. ${ }^{27}$ Sözü edilen söylemler kısaca değerlendirilecek olursa biyolojik seleksiyona insan elinin karışması insanın özüne yapılan

$22 \mathrm{Bu}$ hususta Aristoteles'in insanları eşitsizliğin daima istikrarsızlık getireceği konusundaki uyarısını hatırlatmakta yarar vardır. Bk. Timothy Synder, Tiranlık Üzerine Yirminci Yüzyıldan Yirmi Ders, çev. Zeynep Enez (İstanbul: Olvido Kitap, 2019), 11.

23 Tedavi amaçlı klonlama. Bk. Seyalığlu vd., "Klonlamaya Genetik, Etik ve Hukuksal Açıdan Yaklaşım”, Adli Tıp Dergisi 21/2 (2007).

24 Üretim amaçlı olup tam ve sağ bir insanın üretilmesi hedeflenir. Bk. Seyalığlu vd., “Klonlamaya Genetik, Etik ve Hukuksal Açıdan Yaklaşım".

25 Lewis'e göre söz konusu bu yeni insani gelişme teknolojileri, insan olmanın ne demek olduğunu denememiz ve anlamamız için bize meydan okuyor. Pragmatizme dayanan bir felsefe olan Postfenomenoloji, insanı geliştirme konularını temel alarak incelemek için çok uygundur. Postfenomenolojiyi insani gelişme tartışmalarına dahil etmek hem transhümanistlerin hem de biyo-muhafazakarların eksikliklerini ele alabilir ve temel sorunları anlama yeteneğimizi geliştirir. Bk. Lewis, "Hello Anthropocene, Goodbye Humanity: Reframing Transhumanism Through Postphenomenology", Glimpse 19 (2018), 80.

26 Dominique Lecourt, İnsan Post İnsan, çev. Hande Turan Abadan (Ankara: Epos Yayınları, 2005), 85.

27 Lecourt, İnsan Post İnsan, s. 85. 
ciddi ve yok edici etkilere sahip bir müdahale olmasının yanı sıra adaletsizliği ve eşitsizliği ortaya çıkaracak durumlar olarak da hukuk biliminde değerlendirilmelidir. Hukukun tarafsız ve bağımsız olduğu yönündeki köklü inanış postmodern düşünceyle birlikte şimdilerde yerini hukukun sorgulanması gerektiğine dair eleştirilere bırakmıştır. Dolayısıyla eşitlik, özgürlük ve insan hakları bünyesindeki hukuki kutsal söylemlerin yapıbozuma uğratılması gerektiğini söylemek mümkündür. Bu durum hukukun ideolojikliği hususu olarak postmodern dönemin tartışmaları arasında yerini almaktadır.

Teknolojik ivmenin artmasıyla birlikte yasaların teknolojiye uyum sağlaması adına değişmesi gerektiği yönünde geniş bir fikir birliği söz konusu edilmekle beraber hukuk tarihinde dili, ırkı, rengi, cinsiyeti, milleti ve dini inancı gibi etmenlerin neden olduğu önyargıların neticesinde verilen kararların adaletsizliğine dair birçok örnek mevcut. Kimliğe ilişkin faktörlerin yapay zekâ algoritmaları sayesinde minimize edilmesiyle verilecek kararlarda adaletin tarafsızlığı sağlanabilecektir.

Dikkat çekmek istediğimiz bir diğer husus hukuki ihtilaflara neden olan kimlik ve farklılık tartışmalarında adaletin tesisinin robohakimler aracılığıyla giderilebileceği bir paradigma değişikliğidir. Söz gelimi insanlar gibi hatalara düşmeyerek tüm kararların aynı yüksek hukuki standardı uygulayabilen yapay zekâ sistemleri olarak robohakimler gündeme gelmektedir. Bu yolla uzun ertelemelerin ve yüksek maliyetlerin neden olduğu hatta kimi zaman adaletsizliklere sebep olan hukuki süreçlerin robohakimler yoluyla otomatikleştirileceği bir dönem dillendirilmektedir. Robohakimlerin bütün insanları yasa önünde eşit yargılamasının mümkün olabileceğinin yanı sıra herkese aynı ve eşit tutumlar sergileyeceği robohakimler, hukukun bütünüyle önyargısız ve şeffaf bir şekilde uygulanabilmesine olanak tanıyacak şekilde programlanacaktır. Böylelikle istenerek ya da istenmeyerek de olsa insani önyargılar (açlık, yorgunluk gibi faktörler) robohakimler aracılığıyla son bulabilecektir. Ayrıca insan hakimlerin önemli bir noksanlığı da vakanın bütün inceliklerini irdeleyecek yeterli zamanlarının olamayışı karşısında robohakimlerin bir yazılımdan çok daha fazlası olmalarından ötürü bütün beklemedeki davaları seri bir biçimde olmasa da eşzamanlı inceleyerek rahatlıkla kopyalanabilir ve dava sürecinde kendine ait bir robohakime sahip olabilir. Kısacası son teknolojili adli tıp tekniklerinden cinayetlere kadar 
pek çok alanda yeterli teknik bilgiyle donatılmış robohakimler, insan hakimlerden çok daha üstün yapıda sınırsız belleğe ve öğrenme kapasitesine sahip olabilecektir. ${ }^{28}$

Bütün bu gelişmelerin ışığında ifade etmek gerekirse önyargıdan münezzeh, yetkinlikte sınır tanımayan ve şeffaf olan böylesi yazılımlar eşliğinde etkili ve adil bir yargılamanın olabileceğine dair inanç her geçen gün artmakta olup bu durumun kimlik ve farklılık meselesinde adaletin imkânına dair sorgulamalarda da etkili bir güzergâh olacağı yönünde kanaatler mevcut olabilmektedir. Post-antropolojik felsefeler, insanı içinde yaşadığ farklılıklar kapsamında ele alarak insanı insan kılan özelliklerin çeşitliliğiyle onu yorumlayarak öznelerin evrensel ortak kimliklerinin artık mümkün olmadığını savunmakta olup çoğulcu kimlik politikalarını yeğlemektedir. Bu açıdan post-antropolojik fikriyatta adalet, farklılıkların eşit temsil edilmesi bakımından çoğulculuk ve çeşitlilik anlayışlarına dayanmaktadir.

\section{Bilişsel Melezleşme}

Biyolojik melezleşmenin yanı sıra bilişsel melezleşmenin (hibridizasyonun) tartışıldığı önermeler de hem insan doğasına hem de hukuk alanına ilişkin yürütülen tartışmalara farklı bir boyut katmaktadır. Nitekim, "The Extended Mind" (Genişletilmiş Zihin veya Yayılan Zihin) teziyle adından söz ettiren Andy Clark, Doğuştan Yarı İnsan Yarı Makine Canlılar mıyız? adlı makalesinde kendi bedeninde elektronik olarak hiçbir müdahalenin bulunmadığını, vücudunda silikon çip²9, "retinal implant"30, "kohlear implant" 31 ya da kalp pilinin bulunmadığını hatta gözlük dahi kullanmadığını ne var ki günden güne daha çok siborg haline geldiğini ve sadece kendisinin değil bizlerin de siborglaştığını belirtir. ${ }^{32}$ Melezleşmenin (hibridizasyonun) oldukça normal olduğunu

28 Max Tegmark, Yaşam 3.0 Yapay Zekâ Çă̆̆nda İnsan Olmak, çev. Ekin Can Göksoy (İstanbul: Pegasus Yayınları, 2019), 142-143.

29 Örneğin, "Silikon beyin çipi" düşünce deneyini ele alacak olursak beyninizdeki nöronların zihinsel kapasitelerinizi (örneğin hafızanızı) bozduğunu ve etkilediğini düşünelim, böylece doktorlar doğal nöronlarınızın bir kısmını silikon çiplerle değiştirmeye başlarlar. Bu silikon yongaları, değiştirdikleri nöronların aynı işlevlerini yerine getirmek için programlanmıştır. "Yapay nöronlar" olarak çalışırlar. Aşırı bir durumda, bu değiştirme işleminin biyolojik beyninizin hiçbir parçası kalmayana kadar devam ettiğini hayal edebiliriz. Filozoflar, bu durum devam ederken zihinsel yaşamınıza ne olacağ ${ }_{1}$ hakkında farklı görüşlere sahiptir. Rol fonksiyonalistleri, çipler gerçekten değiştirdikleri nöronlarla aynı işlevleri yerine getirdikleri sürece, zihinsel yaşamınızın etkilenmeyeceğini söyler. Bk. Karina Vold, "The What and Where of Mental States: On What is Distinctive about the Extended Mind Thesis", Minds Online (Erişim 10 Haziran 2020).

30 Tavuk karası hastalığından ötürü görme duyusunu sonradan yitiren insanların görme seviyesini yükselterek görüş imkânını kısmen sunan biyomedikal bir implant türüdür.

31 İsitme kaybı olanlara sesin modifiye edilerek iletilmesine olanak sağlayan bir nöroprotezdir.

32 Andy Clark, “Doğuştan Yarı İnsan Yarı Makine Canlılar mıyız?", Yeni Hümanistler İnsandan Evrene Son Bilimsel Tartışmalar, ed. John Brockman (Ankara: Tübitak Popüler Bilim Kitapları, 2014), 46. 
vurgulayan Clark'a göre toplama hesabı yaparken bile kalemler gibi "şeffaf (transparent) teknolojileri" rutin olarak kullanmaktayız ve bu durum biyolojik ve biyolojik olmayan elementlerin kombinasyonlarını değiştirdiğimizin ifadesidir. ${ }^{33}$ Clark'ın dikkat çektiği husus bilişsel bir melezleşmeye doğru bir eğilim içinde olduğumuz ve günümüzde bilişsel teknolojilerin kullanımının, erişiminin ve dönüştürücü güçlerinin giderek artmış olmasıdır. İnsanın ne tür araçlara gereksinim duyduğu ve onları kullanma şeklinin zihnimizi dolayısıyla da insan doğasını değiştirdiğini hesaba katacak olursak extended mind tezine biraz daha yakından göz atmakta fayda vardır.

Andy Clark ve David Chalmers tarafından yayınlanan "The Extended Mind" (Genişletilmiş Zihin veya Yayllan Zihin) tezi “zihin nerede" sorusuna cevap vermektedir. Genişletilmiş bir zihin ve aktif bir dışsallığı savunmasıyla dikkat çeken bahsi geçen düşünürlerin nezdinde bilişsel süreçler tamamen kafanın içine hapsolmamıştır. Esas savları, dış dünyanın zihnin bir parçası olduğudur. ${ }^{34}$ Genişletilmiş zihin tezi, insan zihnini oluşturan bilişsel süreçlerin bireyin fiziksel ve sosyokültürel ortamının uygun kısımlarını içerecek şekilde bireyin sınırlarının ötesine ulaşabileceğini iddia eder.

$\mathrm{Bu}$ tezin savunucuları, insanın oldukça tanıdık olan zihinsel durumlarının bile kısmen insan kafasının dışında bulunan yapılar ve süreçler tarafından gerçekleştirilebileceğini savunmaktadırlar. ${ }^{35}$ Öznenin bilişsel süreçleri ve zihinsel durumları kısmen varlıklar (entities) tarafından oluşturulabilir bu varlıklar bilişsel süreçleri yönlendirmede doğru rolü oynadıklarında, öznenin dışındadır. ${ }^{36} \mathrm{Bu}$ bakımdan genişletilmiş zihin tezi $(\mathrm{EM})$, mantalitenin sadece beyinde hatta cildin sınırları içinde yer alması gerekmediği iddiasında bulunur. ${ }^{37}$ Yani biyolojik olmayan kaynaklar, insan beyninde çalışan süreçlere uygun şekilde bağlanırsa, kendi başlarına gerçekten bilişsel olarak sayılan daha büyük devrelerin parçalarını oluş̧turabilirler. ${ }^{38}$

Genişletilmiş zihin tezinin ortaya koymuş olduğu sav kısaca değerlendirilecek olursa, zihnimizin işleyişinin, biyolojik-olmayan dış kaynaklarla iş birliği yapan ve organize etme yeteneğine sahip bir yapıda olduğu görülür. Bu noktada geleceğimizin kapısında duran

33 Lynne Rudder Baker, "Persons and the Extended-Mind Thesis", Zygon: Journal of Religion and Science, forthcoming, (Erişim 10 Haziran 2020).

34 Andy Clark vd., “The Extended Mind”, Analysis 58/1 (1998), 8.

35 Julian Kiverstein vd., Oxfordbibliographies, "The Extended Mind Thesis", (Erişim 07 Haziran 2020).

36 David Chalmers, Extended Cognition and Extended Consciousness (Erişim 10 Haziran 2020).

37 Baker, "Persons and the Extended-Mind Thesis", 1.

38 Chalmers, Extended Cognition and Extended Consciousness, 3. 
"tekillik" (singularity) kuramını vurgulamakta fayda vardır. Teknolojik tekillik (singularity): Gelecekte yapay zekânın insan zekâsının ötesine geçerek medeniyeti ve insan doğasını radikal bir biçimde değiştireceğine inanılan hipotezsel nokta olarak tanımlanmaktadır. ${ }^{39}$ Biyoteknoloji, süper uzun ömürlülüğe ulaşmanın yanı sıra, kendimizi "post-human" olma noktasına kadar geliştirmemize de yardımcı olabilir ve bu da daha sonra tekilliğe yol açabilir. ${ }^{40}$

Bizlerin donuk makinelerden, insani niteliklere sahip fakat insandan daha kusursuz makinelere geçiş aşamasında bulunduğumuzu ve tekillik evresinin ilk aşamalarında bulunduğumuzu bildiren Kurzweil, içinde bulunduğumuz yüzyılın ilk yarısında oluşturulacak biyolojik olmayan bir zekânın ${ }^{41}$ zamanımızdaki insan zekâsını aşarak ondan bir milyar kat daha güçlü olacağını haber verir. Dünyasını kusursuzlaştırmak adına "insanın yapması gereken son icat, yapacağı ilk üstün zekâlı makinedir" ve bu zekâ insan zekâsının tamamından bir milyar kat daha güçlü olacaktır ve daha sonra her şeyi bu üstün zekânın kendisi yapabilecektir. ${ }^{42} \mathrm{Bu}$ durumla birlikte hem gerçekten köklü hem de insanın yeteneklerinde temel ve şiddetli bir dönüşümü temsil edecek bir değişim olacaktır. İnsanlığımızı değil biyolojimizi aşacağımızı söyleyen Kurzweil, tekilliğin "biyolojik düşüncemiz ve varlığımız ile teknolojimizin birleşmesinin" zirve noktasını temsil edeceğini yine "insani olan ile biyolojik köklerimizin ötesine" varan bir dünyayla sonuçlanacağını vurgular.

Bedenin doğaya bağımlı sınırlılı̆̆ından kurtularak kusursuzlaşma sürecinde üstün bir yapay zekâ üretebildiği takdirde dünyanın da çok kısa sürede bildiğimiz dünya olmaktan çıkabileceğine dikkat çeken Kurzweil'in sözünü ettiği bu dönemin post-human açısından esas karakteristiği, hayatının nerdeyse tüm evrelerine uzanan bir değişim ve dönüşümü yansıtması ve yaşama anlam yüklediğimiz kavramları da kapsayan bir yapı sergilemesidir. Dolayısıyla Kurzweil gibi transhümanistlere göre tekillik (singularity) döneminde değişim dinamizmini net bir biçimde gözlemlemenin mümkün olduğu kavramlardan biri de kuşkusuz adalet kavramıdır.

Kurzweil'e göre singularity sürecinde hukuk sisteminin ve buna bağlı politikaların da ekseriyetle eksik kalan yönlerini gidermeleri gerekecektir. “İnsanın bilinç sahibi bir canlı

39 Amnon H. Eden vd. Singularity Hypotheses: A Scientific and Philosophical Assessment (Dordrecht: Springer, 2012), $1-2$.

40 Abukar, Transhumanism: Biotechnology and its Role in the Singularity.

41 Yeni kusursuz makineler üreterek insan dünyasını kusursuzlaştırabilecek olan bir üstün zekâ.

42 Ray Kurzweil, İnsanlık 2.0, çev. Mine Şengel (İstanbul: Alfa Yayınları, 2018), 22-23. 
olmasına dayandırılan pek çok hukuk ilkesine istinaden ilk hukuki talep 2003 yılında, bilinç sahibi olduğu iddia edilen bir bilgisayarın fişinin çekilmesini engellemek için talepte bulunulmasıyla tartışmaya açılmıştır." 43 Bu örnekten de anlaşılacağı üzere hukuk ilkeleri ve hak taleplerinin muhatabı olan aktörler insan özneleri olmayıp yapay zekâ sahibi bilgisayarlar olarak karşımıza çıkmaktadır. Kuşkusuz bu durum insanı eşsiz kılan ve sadece kendisine mahsus olduğu sanılan hak taleplerinin artık insan dışı aktörleri de kapsadığının açık bir ifadesidir.

Dolayısıyla genişletilmiş zihin teziyle birlikte tekillik kuramı da Descartes'in öne sürdüğü zihin-beden ayırımının aksine zihin-beden iş birliği olarak okunabilir ve biyolojik olmayan kaynakların varlığı da hesaba katılarak insan beyninin rolü bu perspektiften yorumlanabilir. Her ne kadar beynin rolü özel ve önemli olsa da her şeyin beyinle sınırlı olmadığını savunan her iki düşünce de esasında beynin biyolojik sınırlarının ötesine vurgu yapar. Ayrıca söz konusu durum beyin-dışı araçları da hesaba katarak biyolojik sınırları geçebileceğini göstermesi bakımından modern insanın aklıyla yani salt beyniyle erişmiş olduğu ayrıcalıklı ve her şeyin efendisi olma konumunu basite indirgeyen bir tutum olarak değerlendirilebilir.

Bütün bunları bir araya getirdiğimizde diyebiliriz ki büyük bilimsel gelişmelerin meydana geldiği içinde bulunduğumuz zaman diliminde düşünürlerin, antropologların ve eleştirmenlerin yürüttüğü entelektüel tartışmaların odağında yer alan post-human'ın alacağı bu yeni biçimin herhangi bir hukuki ihtilafta ne şekilde muhatap alınacağı hususu, hukuk alanında ciddi değişim ve dönüşümlerin yaşanacağının habercisi niteliğindedir. Söz gelimi bir faciaya neden olabilecek herhangi bir durum karşısında hukuki öznenin insan değil bir robot ya da yapay zekâ olması durumunda yargılama nasıl gerçekleşecektir, cezai işlem uygulanacak mıdır? Uygulanacaksa nasıl uygulanacaktır, bu kapsamda ihtiyaç ve talepler nasıl değerlendirilecektir? İnsan yaşamının yeni pratikleri olarak zuhur eden ve bilimin telkin ettiği ölüm-yaşam, insan bedeni, döllenme, soy zinciri gibi temellere dayanan yeni kavramları hukuken kabul edecek miyiz? Tüm bunlara ilişkin zihinlerde oluşan soru işaretleri nasıl giderilecektir? Görüldüğü üzere bu durumun hukuka ve adalete yansımalarının nasıl olacağı merak konusu olmakla beraber robotun yargılanmasına dair

43 Ezgi Ece Çelik, “Antroposen ve Posthuman İnsan Çağı'nda İnsan Sonrası Olmak”, Cogito: İnsan Sonrası 95-96, 151. 
akla gelen ilk cezai işlem türü fişinin çekilmesi gibi basit bir ceza yöntemi olabilmektedir. Böylesi bir durumda adaletin gerçekleşmiş olup olmayacağı muğlaklığını korumaktadır.

Özellikle belirtilmelidir ki kimi zaman tehdit ve güç odağı haline gelebilen teknoloji ve ilaç şirketleri, hükümetler ve uluslararası güç unsurları bilimi ve tekniği çıarları adına kullanırken oluşan tahakkümle ve müdahalelerle gerçekleşen durum insanı insan yapan etkenlerin de ortadan kalmasına neden olmaktadır. Bunun en bariz örneği geçmişte büyük bir kıyıma neden olan Hiroşima'ya atılan atom bombasıdır. Günümüzde ise Orta Doğu'da ve Afrika'da gözlenen iç savaşların ve gerilimlerin esasında hem silah sektörüne hem de bunun üretimini yapan ülkelerin piyasa ekonomilerine büyük kazanç sağladığı gerçeğini göz önünde bulunduracak olursak bu durumun insan haklarını ne derece ihlal ettiği ortadadır. Dolayısıyla bugün insan hayatını kolaylaştırmak adına kullanılan ve üretilen robotik varlıkların gelecekte hükümetler arasındaki güç yarışında insani kıyıma neden olacak silahlara dönüşüp dönüşmeyeceği de tartışmalı bir konudur. Özellikle belirtilmelidir ki bugün kullandığımız ulaşım, iletişim, elektronik veya nükleer alanda karşılaşılan birçok yeni teknolojik gelişmenin temel motivasyonu militarize olan savaş ekonomisidir. ${ }^{44}$

Bilimin ve tekniğin egemenci tutumunun gücü elinde bulundurmasını ve insan doğasına ciddi zararlar vermesini siborg veya robot teknolojisi açısından ele alacak olursak türlerin senteziyle beraber insan ırkının evirildiği bu kritik nokta insan doğasının geleceği adına pek de umut verici görülmemektedir. Savaş teknolojilerinin biyolojik silahları da hegemonyasına alması gücüne güç katarken olup biten hadiseler bilginin güçle buluşmasının en büyük resmini ortaya koymaktadır. Nitekim son yıllarda bugüne kadar kutsal görülen hukuksal kavramların uluslararası arenada yaşanmış olan hadiseler karşısında geçerli olmadıklarını gözlemlemek mümkündür. Dolayısıyla hukukun sadece bir güç ilişkisi olarak algılanıp algılanmayacağı hususu tartışılmakta olup söz konusu tüm bu hadiselerin (Hiroşima'ya atılan atom bombası, Holokost, Filistin meselesi, Suriye iç savaşı gibi) güç ilişkileri ile yakından bağını görmemek mümkün değildir. Bu noktada Arendt'in söylemlerine kulak verecek olursak hükümetlerin; yurttaşların bütün hayatı üzerinde egemen güç haline geldiği, kısacası totaliter oldukları her durumda hiçbir geleneksel yararcı hukuk, ahlak ya da sağduyu kategorisinin artık onların eylem dizilerini kabullenmemize, yargılamamıza veya öngörmemize yardımda bulunmadığı ve diğer değer sistemlerinden

44 Örneğin; mikrodalga fırınlar, dronlar, radar teknolojileri, internet vs. 
tamamen ayrı bir değerler sistemine göre işlemeye başladıkları söylenebilir. ${ }^{45}$ Dolayısıyla tüm bu yıkıcı durumların ekonomiyle ve kazançla olan bağının gün gibi ortada olduğu tartışmaya açılabilir.

\section{3. İnsan Özünün Tahribi ve Hukuk}

Nietzsche tarafından ilan edilen Tanrı'nın ölümü ve sonrasında tutulan yas yerini insanın ölümüne bırakırken ölen insan figürü de yerini günümüzün post-human'ına bırakmaktadır. Sibernetik organizmalar (siborglar), robotlar, yapay insanlar, ceninler, "insanhayvan kimeralar146", tasarım bebekler, klonlar, "replikanlar" gibi kurgusal varlıklar hatta sürekli bitkisel hayatta olanların bile tam manasıyla insan olup olmadıkları şeklinde gündemde olan sorular ve bu sorularla bağlantılı olarak ele alınan yeni insan tanımları yeni hukuki tartışmalara ve hak arayışlarına zemin hazırlayacağa benziyor.

Bitki ve hayvanları ilgilendiren biyoteknolojinin çeşitli yönleri dikkate alınacak olursa bu alandaki biyoteknolojik faaliyetlerin biyosferin bütünlüğü ve tüm ekosistem üzerinde hem olumlu hem de olumsuz olarak gerçek etkisinin olduğu gerçeğini inkâr etmek mümkün değildir. Bütün bunlar bilimsel, teknolojik, etik, çevresel, politik, dini, kültürel, sosyal ve ekonomik açıdan önemli konulardır. ${ }^{47}$ Odaklanması gereken esas husus bilimsel bilgi ve teknolojinin biyo-dünyaya, insan varoluşunun alanına özel bir dikkat gösterilerek uygulanmasidir.

Biyoteknoloji konusundaki çalışmalardan elde edilen sonuçlar, insanlığın ortak yararı için kullanılabileceği gibi gücün menfaati doğrultusunda insan özünü tehdit edecek şekilde kişiye, zamana, var olduğu mekân ve coğrafyaya göre kötücül bir güce de dönüşebilir. Bir başka anlatımla bilim ve ticaret ortaklığının egemen olması gibi bir durumda bilimin ekonomi ve politikayla karşılıklı etkileşim halinde olmasının oluşturacağı gücün niteliği oldukça önemlidir. Çünkü günümüzde bilim, araştırma ve şirket menfaatleri iç içe geçmiş durumdadir.

45 Hannah Arendt, Totalitarizmin Kaynakları 3, çev. İsmail Serin (İstanbul: İletişim Yayınları, 2014), $283-284$.

46 Kimera biyoteknolojisi tartışmalı olduğu kadar önemli bir konudur. Bilim adamları, embriyonik hücreleri bir türden başka bir türün hücrelerine çeşitli tekniklerle çeşitli gelişim aşamalarında sokarak kimeralar yaratabilirler. Varlık geliştikçe, hücreler birbirine bağlanır ve birlikte büyür. Bilim adamları ayrıca bir hayvandan diğerine dokuları cerrahi olarak aşılayarak kimeralar da oluşturabilirler. Örneğin, birçok güncel deney, insan beyin hücrelerinin farelere veya diğer primatlara yerleştirilmesini içerir. Bk. Michael Etim, "Human Existence, Biotechnology and the Challenges of Transhumanism", The International Journal of Engineering and Science 10/2 (2021), 77-84.

47 Michael Etim, "Human Existence, Biotechnology and the Challenges of Transhumanism". 
Tıbbi uygulamalarla laboratuvar ortamında insan ve diğer türlerin döllenmesi yoluyla insan yararı için organ üretiminin hukuki ve ahlaki boyutları elbette tartışılmaktadır ancak insan yararına dahi olsa bu tür müdahalelerin ve uygulamaların insan özünü tahrip edeceği de açıtır. Söz gelimi, organ bekleyen hastalara uygun organ üretilmesi ya da tedavisi mümkün olmayan hastalıkların şifresinin çözülmesi bahsi geçen müdahalelerin olumlu tarafını yansıtırken, öjenizm hareketi gibi telafisi mümkün olmayan politik tehlikeler ise olumsuz tarafını yansıtmaktadır. Bu uygulamaların ya da müdahalelerin sinırları, hukukun gücün yanında olup olmamasına ya da müdahalenin etik ve ahlaki boyutunu dikkate alarak göstereceği tavra göre şekillenecektir.

$\mathrm{Bu}$ hususta insan bilimlerine eleştiride bulunan Supiot'un söylemleri oldukça etkileyicidir. Supiot’a göre,

İnsan bilimleri, kesin bilimleri taklit ettikleri ve insanı açılanabilir ve programlanabilir bir nesneye indirgedikleri andan itibaren Batı dogmatizminin kalıntılarından, aydınlatması gereken soruları bilakis ortadan kaldıran, çözülme yolundaki bir bilimsel düşüncenin zavallı izlerinden başka bir şey değildirler. Bunların, beşerî toplumlarını mekanikten ya da biyolojiden ödünç alınan modellere sokmaya çalışmaları boşunadır. Biyolojik organizma kendi normunu kendinde bulurken beşerî toplumunu var eden ve bize bu toplumda bir yerimiz olduğuna dair güvence veren norm dışarda aranmalıdır. ${ }^{48}$

$\mathrm{Bu}$ düşünceden hareketle belirtilmelidir ki insan doğasını ya da özünü kısacası geleneksel insanın ekosistem içindeki konumunu basit bir zeminde değerlendirmekten sakınmamız gerektiğine yönelik söylemlerin sıklıkla dillendirildiği post-antropolojik felsefelerde, insanın zekâsından dolayı sahip olduğu iktidarın neden olduğu yıkımlara ilişkin yoğun eleştiriler söz konusudur. Bu durumda uzlaşmaya varılan nokta insanın biçimlenebilir ve değişen bir varlık olduğu olgusudur.

Tüm bunların işaret ettiği üzere "teknolojinin önce bizi insan kılan şeyleri azaltması, sonra da yok etmesi" ${ }^{49}$ gibi adalet de insani vasıflardan olan vicdan vasfını yitirme tehlikesi taşıyor olabilir. Söz gelimi herhangi bir hukuki uyuşmazlık sürecinde, çözüme ilişkin yazılı kuralların eksik kaldığı durumlarda hâkim ilgili yasal boşluğu vicdani kanıya göre doldurma hak ve yetkisine sahiptir. Buna mukabil, vicdandan münezzeh insan yapımı robotların benzeri bir hukuki uyuşmazlıkta vereceği hükmün, adaleti ne derece

48 Alain Supiot, Homo Juridicus-Hukukun Antropolojik İşlevi Üzerine Bir Deneme, çev. Bilge Açımuz (Ankara: Dost Kitabevi Yayınları, 2014), 14.

49 Gerd Leonhard, Teknolojiye Karşı İnsanlık İnsan ile Makinenin Yaklaşan Çatışması (İstanbul: Siyah Kitap, 2018), 44. 
gözetebileceği ya da hakkaniyetli bir karar olup olmayacağı hususu, post-antropolojik felsefelerde sorgulanması gereken ciddi bir sorun olarak belirir. Bu doğrultuda salt kuralların, adaleti ne derece gerçekleştirdiği de sorgulanmalıdır. Vicdani kanaat, hukuk kurallarına eşlik ettiğinde adaletin tesisi çok daha sağlıklı olacaktır. Böylelikle vicdani kanaat ile adalet arasındaki girift bağın varlığı bir kez daha kendini hissettirmektedir.

Bahsi geçen değerlendirmelerin 1şığında belirtilmelidir ki genetik mühendisliği gibi alanlarda ortaya çıkan gelişmelerin hayal gücümüzü zorladığı ortadadır. Ancak tüm bunlardan elde edilen bilgilerin hepsi bizim kim veya ne olduğumuza yani insan olmanın ne anlama geldiğine ilişkin temel varsayımları kökten sarsmaktadır. İnsanı bir hayvanla veya bir makine ile özdeşleştirmek ve onu tamamen dişsal belirleyicilerle açıklamak insanın sonunu getirmekten başka bir şey değildir. Dahası insanın değersizleşmesi gibi doğa da değersizleşmekte ve biyolojik çeşitliliğin de sonu gelmektedir. Öyle ki bu husus canlıların meta olarak görülmesinin bir ifadesi olan Kartezyen yaklaşımın halen egemenliğini sürdürdügünün izleri olarak da yorumlanabilir. “Bugün hukuk öznesini saf dişı bırakmaya çalışanlar insan varlığını basit bir hesap unsuru olarak ele almayı ve ona hayvan gibi ya da saf bir soyutlama gibi (ki ikisi de aynı kapıya çıkar) davranmayı hedeflemektedir." 50

Biyoteknoloji Yüzyılı adlı çalışmasında Jeremy Rifkin'in dünyanın tüm sorunlarını biyoteknoloji ile çözme hayalinin esasında bir kâbusu barındırdığg ${ }^{51}$ söylemini dikkate almakta yarar vardır. İnsan yaşamını iyileştirmesi beklenen ürünleri üretmek için biyolojik süreçlerin, organizmaların veya sistemlerin kullanılması olarak adlandırılan biyoteknoloji her ne kadar insan yaşamını iyileştirmek için yararlı uygulamaları içeriyor olsa da "Janus yüzlü"52 olarak tanımlanmıştır. Bu onun iki yönlü olduğu anlamına gelir. Bir yandan, teknoloji yoluyla DNA'nın değiştirilmesiyle genlerin bir organizmadan diğerine taşınabilmesi söz konusu iken öte yandan, sonuçları test edilmemiş ve dikkatle karşılanması gereken nispeten yeni tekniklerin de gerektiği söz konusudur. ${ }^{53}$ Dolayısıyla hukuktan beklenen sorunları tartışmayı sona erdirmesinin yanı sıra bazı kriterler belirleyerek böylesi hassas konularda çözüm üretmesidir. ${ }^{54} \mathrm{Bu}$ noktada belirtmek gerekir ki çalışmamız olası

50 Supiot, Homo Juridicus-Hukukun Antropolojik İşlevi Üzerine Bir Deneme, 12.

51 Jeremy Rifkin, Biyoteknoloji Yüzyıll, çev. Celal Kapkın (İstanbul: Evrim Yayınevi, 1998), 16.

52 Janus, bir yüzü sağa diğer yüzü sola bakan iki yüzlü Roma tanrısıdır. Bk. Emet Gürel - Canan Muter, Psikomitolojik Terimler: Psikoloji Literatüründe Mitolojinin Kullanılması (Erişim 01 Mayıs 2021).

53 Saurabh Bhatia, "History, scope and development of biotechnology", Introduction to Pharmaceutical Biotechnology, Volume 1, Basic techniques and concepts (Erişim 01 Mayıs 2021).

54 Hürol Çankaya, Devlet ve Tabiat Biyoteknoloji Çağında İnsan Hakları (İstanbul: Sav Yayınları, 2012), 389. 
tehlikelere dikkat çekerek insan türünü tehdit eden sorunları hukuk ve adalet bağlamında gündeme almayı amaçlıyor olduğundan biyoteknoloji uygulamalarının (besin zincirinin bozulması, biyolojik silah yapımı, yanlış aşılama ve gübreleme, tarım ilaçlarının biyolojik silah olarak kullanımı vs.) olası zararlarının insanlık ve ekosistem üzerindeki etkilerini hukuki ve etik zeminde dikkatle tartışılmasında fayda vardır. Biyoteknolojiler karşısında saptanabilecek endişenin olası motiflerini özetle sunacak olursak bazı transhümanizm eleştirmenleri, daha güçlü teknolojinin tıpkı çevresel sorunlarda gözlemlendiği gibi dünyaya zarar verebileceğini ileri sürmektedir. Ayrıca sosyal refahın da zarar görmesinden endişe duyan eleştirmenler, teknolojik işsizlik veya artan mali eşitsizlikler gibi ciddi problemlere de dikkat çekmektedirler.

\section{Sonuç}

Yeni alternatif terimlerin doğmakta olduğu bu paradigma değişikliğini uygarlığımızdaki insanın yalnızca teorik değil aynı zamanda pratik yok oluşu olarak da okuyabiliriz. Aktüel meselelerin odağında bulunan biyoteknoloji uygulamalarının gerek insan doğasına gerekse adalete yönelik tavrı üzerinden temellenen argümanları ontolojik boyutlarıyla irdelemeye çalıştı̆̆ımız bu çalışmamızın ana savı, insana dair tasavvurların ve adalet kavramının gerçekten değiştiği ve bu değişimin hukuk bilimine de doğrudan ve dolaylı olarak yansıdı̆̆ıdır.

Sonuç olarak belirtilmelidir ki insanlık kendisini adeta öz varlığından dışlama noktasına gelmektedir. Çünkü biyoteknoloji uygulamaları bize doğamızın bozulamaz temelleri olarak algıladı̆̆ımız ve kabullendiğimiz şeyi değişikliğe uğratma imkânı sunmaktadır. Bütün bunları bir araya getirdiğimizde hem biyoloji hem de teknoloji arasında gerçekleşen evrimsel etkileşim örüntüsünün ve teknolojik motivasyonun bizleri getirdiği nokta güçle özdeşlemiş durumdadır. Doğacak kuşakların ve gelecek insanlığın insanca yaşaması ve adaletin anlam bütünlüğünün zedelenmemesi için bilim ve teknoloji etkinliği hukuk dünyasındaki gereksinimlere ve etik değerlere uygunluk ve kabul edilebilirlik açısından gözden geçirilmelidir.

Post-human'ın adalet anlayışının nasıl boyut değiştirdiğine ilişkin anlam arayışına katkı sunmayı amaç edinen bu çalışma çă̆ımızda adaletin ne'liğini söylemese dahi adaletsizliğin ne olabileceğine işaret etmektedir. İnsanlığı yok etme potansiyeli taşıyan “bilim-teknoloji-biyoloji” odaklı meselelere yer verdiğimiz bu çalışmada mesele sadece 
siborg veya robotların insanlar üzerinde kuracakları bir hakimiyet meselesi olmayıp gücün hangi amaçlarla kullanılacağı, adil, etik ve meşru bir zeminde inşa edilip edilmeyeceği meselesidir.

Çağdaş dönemde beliren sorunlar adalet kavramını doğrudan etkileyebilmektedir. $\mathrm{Bu}$ bakımdan yeni koşullara elverişli, yeni yaşam kiplerinin icat edeceği insan, mevcut form ve düzenden ayrılmaya başladığı an adalet anlayışı da sekteye uğrayabilmektedir. Kanaatimizce posthuman için yaşamsal olması gereken esas parametre, kendine ve dünyaya bir anlam katmak ve anlamsızlık içinde boğulmamak adına etiği ve adalet duygusunu yani insani değerleri görmezden gelmemesidir. Bunu sağladığı müddetçe varlığını koruyabilir ve varoluşuna bir anlam kazandırabilir.

Daha kapsamlı ifade etmek gerekirse, yeniden icat etmek durumunda kaldığımız yaşam pratiklerinden biri olan hukuk bilimi yapay zekâ ve yapay yaşamla ilgili tutumunu geliştirmelidir. Yaşamı şimdilik dolaylı olarak kapsamış gibi gözükse de biyoteknoloji tüm değerleri sarsmakla kalmamakta, aynı zamanda insan haklarının problemli alanlarına yenilerini de eklemekte ve durum hukuk alanına da sirayet etmektedir. Bu nedenle iktisadi temel üzerinde varlığını konumlandıran biyoteknoloji uygulamaları sadece insanı değil tüm canlıları değiştirme potansiyeline sahip olduğu için bu uygulamalara yönelik temkini elden birakmamak gerekir. 


\section{Kaynakça}

Abukar, Shayma. Transhumanism: Biotechnology and its Role in the Singularity. Erişim 25 Nisan 2021. https://www.ukessays.com/essays/sciences/transhumanism-biotechnology-role3163.php

Arendt, Hannah. Totalitarizmin Kaynakları 3. çev. İsmail Serin. İstanbul: İletişim Yayınları, 2014.

Baker, Lynne Rudder. Persons and the Extended-Mind Thesis, Zygon: Journal of Religion and $\begin{array}{lllll}\text { Science, } & \text { forthcoming. } & \text { Erişim } & 10 & \text { Haziran }\end{array}$ http://people.umass.edu/ lrb/files/bak09perM.pdf

Batukan, Can. Robo-tizm Robot, Android, Sayborg ve Yapay Zekâda Ruh Üzerine. İstanbul: Altıkırkbeş Yayınları, 2017.

Bhatia, Saurabh. "History, scope and development of biotechnology". Introduction to Pharmaceutical Biotechnology, Volume 1, Basic techniques and concepts. Erişim 01 May1s 2021.https://iopscience.iop.org/chapter/978-0-7503-1299-8/bk978-0-7503-1299-8ch1.pdf

Braidotti, Rosi. "Feminist Post-Postmodernizmin Eleştirel Bir Kartografyası". Cogito, Feminizm 58 (2009).

Braman, Sandra. "Defining Information Policy". Journal of Information Policy 1, (2011), 1-5.

Braman, Sandra. "Posthuman Law: Information Policy and the Machinic World". First $\begin{array}{lllll}\text { Monday. } & \text { Erişim } & 7 & \text { Nisan } & 2017 .\end{array}$ https://firstmonday.org/ojs/index.php/fm/article/view/1011/932

Chalmers, David. Extended Cognition and Extended Consciousness. Erişim 10 Haziran 2020. http://consc.net/papers/excexc.pdf

Childers J. ve G. Hentzi (ed.). The Columbia Dictionary of Modern Literary and Cultural Criticism. New York: Columbia University Press, 1995.

Clark, Andy. "Doğuştan Yarı İnsan Yarı Makine Canlılar mıyız?". Yeni Hümanistler İnsandan Evrene Son Bilimsel Tartışmalar. ed. John Brockman. 46-54. Ankara: Tübitak Popüler Bilim Kitapları, 2014.

Clark, Andy. vd. "The Extended Mind". Analysis 58/ 1 (1998), 7-19.

Cyborg Foundation. Erişim 28 Nisan 2021. https://www.cyborgfoundation.com

Çankaya, Hürol. Devlet ve Tabiat Biyoteknoloji Çağında İnsan Hakları. İstanbul: Sav Yayınları, 2012.

Çapar, Bengü. “Bilgi Politikası”. IFLA 1995'e doğru Türk Kütüphaneciliği Sempozyumu ve I. Türk Kütüphaneciler Derne ği Genel Konferansı Bildirileri, (1997), 16-20.

Çeçen, Anıl. Adalet Kavramı. İstanbul: Gündoğan Yayınları, 1993.

Çelik, Ezgi Ece. “Antroposen ve Posthuman İnsan Çağı'nda İnsan Sonrası Olmak”. Cogito: Insan Sonrasi 95-96, 2019.

Dağ, Ahmet. Transhümanizm: İnsan ve Dünyanın Dönüşümü. Ankara: Elis Yayınları, 2018.

Dawkins, Richard. The Selfish Gene. Oxford: Oxford University Press, 1976.

Eden, Amnon H. vd. (ed.). Singularity Hypotheses: A Scientific and Philosophical Assessment. Dordrecht: Springer, 2012.

Etim, Michael. "Human Existence, Biotechnology and the Challenges of Transhumanism". The International Journal of Engineering and Science 10/2 (2021). 77-84.

Foster, John Bellamy. Emperyalizmin Yeniden Keş̧i. çev. Çiğdem Çidaml. İstanbul: Devin Yayıncilık, 2005.

Future Fandom. "Transhumanism Criticisms". Erişim 28 Nisan 2021. https://future.fandom.com/wiki/Transhumanism_Criticisms 
Gürel, Emet vd. Psikomitolojik Terimler: Psikoloji Literatüründe Mitolojinin Kullanılması. Erişim 01 Mayis

2021,

https://web.archive.org/web/20170502125147/https://earsiv.anadolu.edu.tr/xmlui/bitst ream/handle/11421/408/448301.pdf? sequence $=1 \&$ isAllowed $=\mathrm{y}$

Haraway, Donna. A Cyborg Manifesto Science, Technology, and Socialist-Feminism in the Late Twentieth Century. Minnesota: University of Minnesota Press, 2016.

Haraway, Donna. Başka Yer. çev. Güçsal Pusar. İstanbul: Metis Yayınları, 2010.

Kiverstein, Julian vd. Oxfordbibliographies. "The Extended Mind Thesis". Erişim 07 Haziran 2020.https://www.oxfordbibliographies.com/view/document/obo-9780195396577/obo9780195396577-0099.xml

Kurzweil, Ray. İnsanlık 2.0. çev. Mine Şengel. İstanbul: Alfa Yayınları, 2018.

Lecourt, Dominique. Insan Post İnsan. çev. Hande Turan Abadan. Ankara: Epos Yayınları, 2005.

Leonhard, Gerd. Teknolojiye Karşı İnsanlık İnsan ile Makinenin Yaklaşan Çatışması. çev. Cihan Akkartal-illker Akkartal. İstanbul: Siyah Kitap, 2018.

Lewis, Richard S. "Hello Anthropocene, Goodbye Humanity: Reframing Transhumanism Through Postphenomenology". Glimpse 19 (2018), 79-87.

More, Max. "Transhumanism: Towards a Futurist Philosophy". Extropy. Erişim 25 Nisan 2021. http://fennetic.net/irc/extropy/ext6.pdf

$\begin{array}{llllll}\text { Posthumanism. } & \text { Oxford } & \text { Dictionary. } & \text { Erişim } & 25 & \text { Nisan }\end{array}$ https://www.lexico.com/definition/posthumanism

Rifkin, Jeremy. Biyoteknoloji Yüzyılı. çev. Celal Kapkın. İstanbul: Evrim Yayınevi, 1998.

Seyalığlu. İ. vd. "Klonlamaya Genetik, Etik ve Hukuksal Açıdan Yaklaşım”. Adli Tıp Dergisi 21/2 (2007), 31-45.

Stiegler, Bernard. "Antroposenden Çıkmak". Cogito: Yerküre Krizi, Dönüşen İnsan 93 (2019).

Supiot, Alain. Homo Juridicus-Hukukun Antropolojik İşlevi Üzerine Bir Deneme. çev. Bilge Açımuz. Ankara: Dost Kitabevi Yayınları, 2014.

Synder, Timothy. Tiranlık Üzerine Yirminci Yüzyıldan Yirmi Ders. çev. Zeynep Enez. İstanbul: Olvido Kitap, 2019.

Tegmark, Max. Yaşam 3.0 Yapay Zekâ Çă̆ında İnsan Olmak. çev. Ekin Can Göksoy. İstanbul: Pegasus Yayınları, 2019.

$\begin{array}{llllll}\text { Transhumanism. } & \text { Oxford } & \text { Dictionary. } & \text { Erişim } & 25 & \text { Nisan }\end{array}$ https://www.lexico.com/definition/transhumanism

Val, Jaime del - Stefan Lorenz Sorgner. A Metahumanist Manifesto. Erişim 25 Nisan 2021. https://metabody.eu/wp-content/uploads/2016/02/A-METAHUMANISTMANIFESTO.pdf

Vold, Karina. "The What And Where Of Mental States: On What is Distinctive about the Extended Mind Thesis". Minds Online. Erişim 10 Haziran 2020. https://mindsonline.philosophyofbrains.com/2016/2016-2/the-what-and-where-ofmental-states-on-what-is-distinctive-about-the-extended-mind-thesis/

Walker, Andy vd. Süper İnsan Teknoloji İnsanlı̆̆ı Yeniden Tanımlıyor. çev. Su Evren, İstanbul: Siyah Kitap, 2019. 